\title{
Eupsychian Management: Organizational Change, Behavior, Motivation, And Trust
}

\author{
C. Kenneth Meyer, Drake University, USA \\ Richard B. Strong, University of Minnesota, USA \\ Jeffrey A. Geerts, Iowa Economic Development Authority, State of Iowa, USA
}

\begin{abstract}
In Part 1 of this real-life incident, Professor Carson is teaching the customary material associated with the multiple theories of leadership, motivation, and organizational behavior. He deviates slightly from the way he normally presents these standard concepts and theories and divulges the concept of Eupsychian Management - a culture in which self-actualizing people behave in ways where trust begets trust and work is viewed as natural as play or rest. The class is given the following website www.interpolis.nl which demonstrates how the built environment of Interpolis relates to its organizational culture and behavior.

In Part 2, the content of a personal interview that he conducted in Tilburg, The Netherlands - the home of Interpolis is elaborated. A new organizational culture based on "trust" - both of employees and customers is revealed. The end performance results and the productivity metrics are unbelievably high. The reader is challenged to address the content of seven penetrating questions and instructions which are part of the learning module; then, is asked to complete the case log and administrative journal entry.
\end{abstract}

Keywords: Interpolis; Trust; Motivation; Sustainability; Change; Organizational Behavior

\section{INTRODUCTION: THE BUILDING BLOCKS OF EUPSYCHIAN MANAGEMENT}

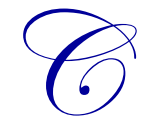

ollege professors who teach management and motivation theory use the writings and theories of Abraham H. Maslow as commonly and as readily as statisticians refer to the writings of Karl Pearson and the notions of chance. Over the years he had tired of teaching about the well-worn acronym of Luther Gulick - POSDCORB (planning, organizing, staffing, directing, coordinating, reporting, and budgeting) although he noted with astonishment that nearly 75 percent of federal civil servants in management still used it as a guiding and useful tool. This semester, Professor Peter Carson was again assigned to teach the introductory class in public administration and, as was his custom, addressing the various schools of thought that were prominent over the years. The names of prominent theorists rolled off of his tongue as he made sure they were pronounced correctly, followed by a sentence or two about their seminal contributions to the field of study: Machiavelli, Rousseau, Hobbes, Montesquieu, Locke, Hobbes, Maslow, Mayo, McGregor, Likert, Follett, Simon, Barnard, Blanchard, Kaufman, Selznick, Taylor, Fayol, and of course Max Weber and Karl Marx - two Germans of Renaissance intelligence. The current stable of academic names was also part of his presentation as he attempted to tell the story of the evolution and development of modern administration: Friedman, Brudney, Meier, Lowi, Drucker, Osborne, Gaebler, and the ageless and ever relevant writings of Dwight Waldo.

Carson's lecture tonight would be on the contributions of Abraham H. Maslow and Eupsychian Management - a culture in which self-actualizing people would not be corralled or bridled. As he spoke about Maslow's Hierarchy of Human Needs, he methodically went from the physiological, security, belonging, self esteem to that of self-actualization - " ... becoming all we are capable of becoming as human beings." Carson was clearly in his element when he lectured on the human relations movement and especially on quintessentially renowned psychologist Maslow. As he warmed up to the challenge he attributed the following assumptions about human behavior and organizations to Maslow, as summarized by Jeffery Seglin in The Enlightened Manager's Guidebook: 
1. People move from one level of need to another - they are not locked in time or at any one level;

2. $\quad$ People desire to work and work is as natural as play or rest;

3. People like to feel important, respected and proud and connected to the group and enjoy teamwork, belongingness, and even group love;

4. $\quad$ People are fair and objective in sizing up their own abilities and those of their colleagues;

5. $\quad$ People prefer joy and a sense of delight more than boredom and they want to do meaningful work;

6. People prefer to be treated as an entire person, rather than as one of so many parts in the organization; and

7. People prefer trust over distrust and love over hatred — they are improvable.

Carson was no stranger to controversy in his classes and this night would not be an exception. A graduate student by the name of Jeremiah Winters, a list line supervisor in the department of transportation, quizzically challenged Carson and stated that "... Maslow's views on motivation and the nature of people defied what actually takes place in real organizations." He went on to observe that people needed to be controlled, directed, and monitored or else they will give away the shop. "Yes," Jeremiah concluded, "...the workers may well be happy, but in business we are all about getting things done and done right — productivity."

Professor Carson patiently listened as others in the class shared their own experiences and discussed the basic nature of people and their needs, wants, and desires. The discussion was full of energy and the class was enjoying the give and take associated with the various theories, opinions, and experiences that were shared. Then, "out of the blue" came a request from Olivia Ward - a quiet, but assertive middle-manager in the Department of Human Services. She had mentioned to the class in an earlier discussion how she often came into contact with the "underbelly of society," and as she said "... it does not paint a beautiful portrait of our basic nature." Then, she asked Professor Carson if he had any practical examples of a "... real flesh and blood organization" that had successfully used some of Maslow's assumptions about motivation that he had outlined in his lecture. Carson smiled approvingly in response to Olivia's question and said that he had an example in mind that he would present at the next class session. He asked the group to surf the Web and discover what an insurance company in the Netherlands was doing in their attempt to change their organizational culture and base it on both internal and external trust — internal trust of its employees and external trust of its subscribers. He then went to the keyboard on the podium and entered: www.Interpolis.org.

\section{INTERPOLIS: A POWERPOINT PRESENTATION OF CONTEXT}

The days went quickly by as Carson prepared a PowerPoint presentation in which some of Interpolis' attributes were characterized:

1. Interpolis employs 25,000 and is the largest insurance company in the Netherlands. Every quarter, employees receive 5 or 6 days of vacation and the average workweek is about 38 hours in length. Work flow management - what comes in and what goes out - is meticulously studied and analyzed. Trust of employees and customers permeates the entire structure and all work processes. For every ten employees, only 7 desks or work stations are provided in the headquarters office building. Interpolis has a flat, decentralized organizational structure. Building space is constructed like a city with four things that inspire workers - work, relaxation, eating, and meeting. And, what is unheard of in the private sector, workers can tell one another of their wages, salaries, and bonuses.

2. Interpolis developed the Flexible Office Concept (FOC); chairs with "big ears" are used for small meetings with a few people and provides an informal, comfortable, and "cozy" environment that is free from outside noise and where confidential matters can be freely discussed.

3. Interpolis found that it had to lay off 700 employees and so it presented the issue to the employees and asked for their suggestions - which were then implemented.

4. Interpolis researched and found that 30 percent of the office space was not used in a conventional office setting; that in 3 out of 10 days the desk was not used. They also discovered that cubicles are good for concentration and that open spaces are good for communication.

5. The company examined its work processes and decided to change the physical way people work. Utilizing FOC (Flexible Office Concept), Interpolis revolutionized the way office space was assigned and used. That is, the associate determines and selects the office space that is best suited for work to be performed - 
cubicle or open space. The employee, on a daily basis, selects the place they will work based on the environment that best fits the activity or task to be performed. What counts at Interpolis "is that the work gets done."

6. Employees are required to take personal responsibility for their behavior and team leaders must let go and give them the needed job related autonomy to perform their jobs. Team leaders at Interpolis found that if they trust their associates, their colleagues will work with a sense of newly found freedom, responsibility, and reciprocal trust. Work time is from 7:00 A.M to 7:00 P.M. and is flexed - team members can chose to come in early and leave early or arrive later and stay later. In the final analysis, what employees do and what they accomplish is what counts. Associates determine what constitutes an average week of work and they manage their own time and resources accordingly.

7. Interpolis has a truly great office space - a building that doesn't resemble an office, but reflects a new corporate mindset for management and employees. A large amount of space is devoted to multi-purpose uses for large meetings, relaxation, conferences, consulting, working, eating and meeting people, etc., with a background of music that is suitable to the activity in progress. The corporation believes that a happy worker works more effectively which results in more productivity. Interpolis also believes that a built environment needs to be compatible with modern management theories (corporate culture), and when this takes place, employee satisfaction goes up, absenteeism goes down, and the turnover rate decreases. In brief, the organization becomes a more knowledgeable learning organization, more fun, more productive, and serves customers better with fewer errors. Associates are asked to talk to customers with "... a smile in their voices." These changes are partly related to their high customer satisfaction levels and they discovered that as people needed new or added insurance protection, they thought of Interpolis as the insurance company of first choice. Accordingly, Interpolis grew from 1,400 employees in 1996 to 6,000 employees in 2004, and has more than 100 offices located throughout the Netherlands.

8. Last, Interpolis invested in those essential information systems that would enhance communication and interaction. With state of the art communication technology in place, employees were free to work from their home office (about 2,500 associates work at home or telecommute several days each week) and experience the same speed and ability to transfer information as they had in their corporate headquarters. Team members found that they tended to use their home office for concentrated, thoughtful work; they used other space in the office consistent with the decisions that needed to be made or the tasks at hand, such as meetings.

\section{QUESTIONS AND INSTRUCTIONS}

1. Please identify and list those elements, traits, or characteristics which you feel are important for an organization to possess if it wishes to be successful in the 2lst Century.

2. Would you be interested in working for an organization that had some of the characteristics and philosophy of Interpolis? Please explain your response.

3. In your own organization, what would you list as some of its defining attributes or characteristics? To what extent, does your own organization compare favorably with what Interpolis has to offer? Please be specific.

4. Would you feel comfortable in presenting to your top management some of the ideas that are central to Eupsychian Management as envisioned by Abraham Maslow? If yes, please explain. If no, please give the reasons why you would feel uncomfortable. 


\section{Part 2: STOP! Please Answer Questions 1 and 2 Above Before Reading Part 2}

\section{PART 2: INTERPOLIS: A REVEALING PERSONAL INTERVIEW}

Based on a personal interview that Professor Carson had a year earlier with a volunteer representative (ambassador) of Interpolis at the Tilburg headquarters, he distributed to the class the written results of a structured interview with Josephine. His questions were wide ranging and dealt with topics as varied as environmental sustainability, organizational norms and conformity, the specialized language used in a new organizational culture, and the genesis of Interpolis and its merger with Acheon. He also solicited some responses that show the interdependency between the "changing nature of work and architectural design," and asked a question on what attracted the representative to Interpolis and what serves a strong retention factor for her now. The results of the interview are transcribed below:

Professor Carson: What happens when an employee goes against the grain or when one disagrees with an established company process or policy?

Josephine: Mavericks are important in the organizational culture of Interpolis. When employees see where change is required to increase speed or reduce cost, for example, or if they want to give voice to an issue such as downsizing, they can present their ideas before a hearing board. As a result of incorporating employees into the decision-making mix, the operational costs of Interpolis have declined, processes have been improved, and efficiency increased. Hearing boards provide an open, transparent, non-threatening forum in which the issue or change at hand can be laid on the table and discussed and analyzed. For instance, the following kinds of questions might be asked: Why is a specific change required? Why are things done in a certain fashion? What would be the end result or effect if a process or policy was altered or changed? We think this type of open, non-threatening environment is necessary in establishing a trusting relationship.

Professor Carson: I can see how the hearing boards work from the employee's point of view, but what happens when the interest of Interpolis and those of the customer collide?

Josephine: Although some other insurance companies in the Netherlands think Interpolis is 'crazy,' when it comes to how we do things here, we disagree and strongly believe it makes complete logical and rational sense. We know from behavioral research that the way we work affects what we accomplish and how we feel. We are not a company made up of bloodless automatons or robots! We want to be acknowledged as mature, responsible, loyal, valued, supportive, comfortable, and joyful adults. In this regard, although it may seem strange to those who do not understand the Interpolis' culture, employees can, in the final instance, chose what is in the interest of their clients even though it may trump their own self-interest or that of the corporation.

Professor Carson: I am interested in how Interpolis deals with sustainability and how it factors this concept into its decision making model?

Josephine: Sustainability is a core value to which we are not only sensitive, but committed. In brief, it is factored into product development, the work processes, and the way we work in our built environment. For instance, Interpolis is a totally digital work environment. Our associates have what information they need on their cell phones and laptops. In this sense, except in those instances where contracts and other legal documents must be hard copy by Dutch law, all other incoming mail and correspondence is digitalized. We are a paperless company! Also, we are concerned on how our office complex is used not only from an individual basis, but how it is used collectively and functionally. We constantly ask how can I learn from you - what advice can I receive from others? We put a premium on knowing ones job - of being an honest, trustworthy, open, loyal, and capable team member.

In addition, we support sustainability through the work at home or telecommuting programs, voucher programs for fitness and health activities (wellness), and the company encourages its members to use mass transportation (bus, train, tram), bicycling, and pedestrian means of getting to and from work or in conducting official business. In the realm of equity and fairness, Interpolis business policies do not differentiate between managers and associates. In addition, we also give bicycles to those who request them - free of charge. The 
Netherlands has a bicycling culture and we do what we can to encourage and sustain this part of our national heritage.

Professor Carson: I have noticed Josephine that you choose your words very carefully when addressing management-employee relations. In the two-three hours we have talked about Interpolis, not once did you mention the commonly used terms of chief, boss, superior, supervisor, or worker or subordinate - the language of hierarchy and competition. You indicated that language affects beliefs and attitudes are often reflected in behavior. How do you see yourself as a team leader or manager?

Josephine: In terms of the Netherlands, we have a complex Dutch language and the word we use for leadership does not translate easily into English. At Interpolis we think of managers as leaders, colleagues, team builders, coaches, motivators, cheerleaders, facilitators, and as partners in a vision team. The leadership attributes and skills that we value are part of a well-thought out human resource management strategy. The term we use is leiding gwende or leiding (leading) plus givende (giving).

Professor Carson: Would you give me just a few ways that Interpolis differs from the other corporations you are familiar with?

Josephine: I will present four major ways that enables Interpolis to develop its uniqueness, and its special employee and customer appeal.

1. The internal norms emphasize the essential quality of having complete trust between associates and team leaders. If you wish for 'trust to grow,' you must provide an environment conducive to its growth. It is like a plant - you need to water it if you wish it to grow and be sustained as a healthy living organism.

2. Loyalty is a two-way street. Employee loyalty is very important to Interpolis and those applicants who have attributes conducive to our special way of behaving and working are selected as associates. Team members are assessed and selected on having the needed skills, attributes, knowledge, and overall competencies essential for the job, plus their organizational fit. Initially the internal team leaders work jointly with psychological consultants in interviewing and rating potential employees on their ability to work in an environment of individual freedom, trust, and responsibility. If one is rejected for employment, the applicant cannot reapply for employment at Interpolis for at least five years. It is very important that Interpolis selects those whose values and behaviors support the building and enhancement of interpersonal trust in the workplace. It bears repeating that the way we work affects what we accomplish and how we feel as colleagues: mature, loyal, joyful, comfortable, valued, supportive, and responsible adults.

3. Additionally, clients - those insured - are also trusted. Just as Interpolis humanized the way of working internally, it also places a human touch on its relationships with customers. For example, associates are expected to pick up the telephone and answer the call before the third ring. This affects the image of Interpolis - its brand. Also, associates talk to the clients with a "smile in their voices." Further, all insurance policies must be written and communicated in 'crystal clear' language - in a normal conversation language - the same way you would like to be addressed and talked with by the corporation. Interpolis' goal is to present its policies honestly, and thus it has eliminated institutional and insurance jargon in its oral and written correspondence and communication. It short, policies and disclaimers are clearly written, transparent, and direct. The word glashelder or 'crystal clear' is the standard used for effective, non-bureaucratic communication.

4. In a unique way, the customer is trusted visibly and implicitly. For example, a customer who has suffered a loss, such a as a stolen television or Play Station, is not asked by Interpolis to produce an original receipt as proof of purchase. Why is this the case? The answer is simple - the customer is a trusted partner as well. Instead, the customer can go the Web Store and select a new television and can even upgrade for a larger size. The customer wants a solution for their problem! Competitor companies feel that the customer wants to be fraudulent - that they want to cheat the insurance company. In fact, Interpolis' research and investigation shows that fraudulent cases did not increase in their extending trust externally - that customers respected the trust they were accorded. So, although the company has an investigative bureau with trained, skilled, and experienced service agents who know what clues to look for as indicators of deception or dishonesty, the customer can leave the receipts for its lost purchases at home! It is very rare or 
uncommon to trust the insured in the business world today that often people 'distrust the trust' they are given. If customers are found to be deceptive or dishonest, however, they are banned, barred, or 'black listed' from securing insurance from any of the Netherland's insurance companies. Of course, this represents a severe penalty for violating the cannon of trust!

5. Interpolis has a unique built architecture that corresponds to the organizations behavioral objectives. It has a white conference room in which decisions are made free from all outside interruptions - a room in which 'light' represents truthfulness in conducting meetings and making decisions. It also has a wisdom room in which people are surrounded by inspirational quotations, admonitions, poetic and philosophical expressions and exhortations. Further, it has a room for dressing and showering for those who walk, bicycle, jog, etc., to work or engage in physical exercise programs. And it has a lactation room that is especially designed for women who breast feed or pump for later use. Interestingly, it has purple brainstorming room in which people are positioned about a round table. Overall, the built environment has architectural design features such as streets, squares, places, and rooms designed to facilitate work, decision, and effective communication. These areas are set off by the ten special area club houses, all with different themes, designed to meet those essential activities that take place in the office: meeting, working, eating, and relaxation. Finally, although there are too many other features to mention here, it has a gourmet cafeteria for employees in which they can entertain clients and experience formal dining at its best. Employees take the food and beverages they wish from the cafeteria and charge themselves for their own purchases - there is no cashier present to keep the employees honest.

Professor Carson: How did you come to work for Interpolis?

Josephine: This is a complex journey that was begun when I was a part-time student employed in the communications unit. Then, insurance did not seem to be an attractive or sexy business in which to work and have a career. However, working at Interpolis was different from what I had imagined about corporate cultures: rigid, dogmatic, inflexible, mundane, monotonous, routine, and bureaucratic. I soon realized I was not thought of as a 'dreaded slot-filler' by management and I responded accordingly as an independent, mature, goal oriented, and enthusiastic adult. Within hours, I began to understand how Interpolis was differentiated from the other large insurance companies in the Netherlands, although it was started in 1969 as an insurance provider for farmers and agricultural organizations. It was a totally new way of working for me - working in an environment of trust, freedom, loyalty, and individual responsibility. A milieu in which these values were mutually reciprocated between all members of the team - our associates with whom we had bonded. In brief, the key factor that attracted me to Interpolis and still has a magnetic draw is the way in which associates identify with a way of working - a culture that integrates people, place, process, customers, and technology in an environment of complete trust, connected by supportive IT hardware that enables effective communication with one another.

\section{QUESTIONS AND INSTRUCTIONS}

5. Now, having read the transcribed interview that Professor Carson had with Josephine, would you change any of the responses you had to the first four questions in this case study? If so, which would you modify or change and why?

6. Josephine mentions that Interpolis has integrated from a strategic management perspective people, place, process, customer, and technology. In your organization, have these elements been systematically addressed in an integrative fashion? Please explain.

7. What have you learned about Interpolis that you believe makes it a truly innovative "star" in terms of corporate culture and could these innovations be replicated in your own organization? If yes, why and if no, why not?

\section{AUTHOR INFORMATION}

C. Kenneth Meyer is Thomas F. Sheehan Distinguished Professor of Public Administration at Drake University. He previously held teaching positions at Winona State University, State University of New York, University of South Dakota, and the University of Oklahoma, Norman, Oklahoma. He has nearly 300 published case studies that appear in numerous venues. His latest books are entitled: Managing People as Assets, Human Relations in Action, 
Managing America's Organizations, Managing Public Service Organizations, Conducting the People's Business, and Organizational Change. He has co-authored other case studies with Richard Strong and Jeffrey Geerts and has dozens of articles in a number of other business, public administration, and criminology journals. His newest book, with Jeffrey Geerts is entitled Nonprofit Management and Leadership Case Studies (2014). E-mail: kenneth.meyer@drake.edu (Corresponding author)

Richard Strong is a Senior Research Fellow at the Center for Sustainable Building Research. He holds a Bachelor's degree in Architecture from North Dakota State, a Master's degree in Urban Planning from McGill University, and a Master's degree in Design from the Graduate Design School at Harvard University. He has worked in both private and public sectors, in governmental and university settings, over the last 30 years. As a leader in the field of sustainability, he has taught sustainable design at Carleton College and is involved in monitoring the Sustainable Buildings 2030. He also teaches in the Graduate Sustainable Architectural Degree program at the School of Architecture at the University of Minnesota. In addition to teaching the Sustainable Values course at Hamline University Graduate School of Management and Business, he teaches several courses in the College of Business and Public Administration at Drake University.

Jeffrey A. Geerts is an Adjunct Professor of Public Administration at Drake University where he has taught graduate level courses in state and local government and environmental policy. He participates in the Comparative Public Policy and Government course (SMART course), and helped facilitate fourteen European learning trips dealing with green urbanism, sustainability, the built environment, and building the community of the future. He presently serves as Special Projects Manager for the Iowa Economic Development Authority leading the organization's sustainable community development efforts. With Professor Meyer, he has coauthored seven books in the field of public administration and public policy and many case studies. E-mail: Jeff.Geerts@Iowa.Gov

\section{REFERENCES}

1. Agocs, C. (1997). Institutionalized resistance to organizational change: Denial, inaction and repression. Journal of Business Ethics, 16(9), 917-31.

2. Anjali, S. M. (1997). Problems and paradoxes in a model of punctuated organizational change. Administrative Science Quarterly, 42(2), 237-75.

3. Argyris, C. (1973). Personality and organization theory revisited. Administrative Science Quarterly, 18(2), 141-167.

4. Bies, R. J., \& Tripp, T. M. (1996). Beyond distrust: 'Getting even' and the need for revenge. In R. M. Kramer, \& T. R. Tyler (eds), Trust in organizations: Frontiers of theory and research (pp. 246-260). Thousand Oaks, CA: Sage Publications.

5. Burke, W. W. (2007). Organization change theory and practice (Foundations for organizational science). Minneapolis: Sage Publications, Inc.

6. Caldwell, C., \& Clapham, S. E. (2003). Organizational trustworthiness: An international perspective. Journal of Business Ethics, 47(4), 349-364.

7. Carnevale, D. G. (1995). Trustworthy government: Leadership and management strategies for building trust and high performance. San Francisco, CA: Jossey-Bass Publishers.

8. Carnevale, D. G. (2003). Organizational development in the public sector. (J. Shafritz, Ed.). Boulder, CO: Westview Press.

9. Clapham, S. E., Caldwell, C., Proctor, G. B., \& Meyer, C. K. (2013). Trustworthiness, justice and the mediating lens. Proceedings of the ASBBS 16th International Conference. Retrieved from http://www.asbbs.org/files/2013/ASBBS_2013_INT_PROG.pdf

10. Costigan, R. D., Ilter, S. S., \& Berman, J. (1998). A multi-dimensional study of trust in organizations. Journal of Managerial Issues, 10(3), 303-317.

11. Delmas, M. A., \& Pekovic, S. (2013). Environmental standards and labor productivity: Understanding the mechanisms that sustain sustainability. Journal of Organizational Behavior, 34(2), 230-252.

12. Fiske, S. T., \& Taylor, S. E. (1991). Social Cognition ( $2^{\text {nd }}$ ed.). New York: McGraw-Hill.

13. Gabarro, L. (1978). The development of trust, influence, and expectations. In A. G. Athos and J. J. Gabarro (Eds.), Interpersonal behavior: Communication and understanding in relationship. Englewood Cliffs. NJ: Prentice Hall. 
14. Golembiewski, R. T. (2008). Organization development: Ideas and issues. New Brunswick: Transaction.

15. Greve, H. R. (1998). Performance, aspirations, and risky organizational change. Administrative Science Quarterly, 43(1), 58-86.

16. Hosmer, L. T. (1995). Trust: The connecting link between organizational theory and behavior. Academy of Management Review, 20(2), 379-404.

17. Interpolis Ambassador. (2008). Personal interview. March, 2008.

18. Interpolis. (2010). About Interpolis. Interpolis. Glashelder. Verzekeringen NV. Retrieved January 2, 2010 from http://www.interpolis.nl/particulier/default.aspx

19. Interpolis. Manual for guided tours of Interpolis. Tilburg: Interpolis.

20. Lewicki, R. J., McAllister, D. J., \& Bies, R. J. (1998). Trust and distrust: New relationships and realities. The Academy of Management Review, 23(3), 438-458.

21. Lewis, J. D., \& Weigert, A. (1985). Trust as a social reality. Social Forces, 63(4), 967-985.

22. Maslow, A. H., Stephens, D. C., \& Heil, G. (1998). Maslow on management. New York: John Wiley.

23. Maslow, A. H. (1997). Motivation and personality ( $3^{\text {rd }}$ ed.). Upper Saddle River, NJ: Pearson Education, Inc.

24. Mawson, A. (2006). Interpolis-Head Office - Tilburg. Rep. London: Advanced Workplace Associates.

25. McCain, J. (2004). Finding the courage within you. New York: Mansueto Ventures, LLC. Retrieved Sept. 1 from www.fastcompany.com/506921/search-courage

26. Merton, R. K. (1940). Bureaucratic structure and personality. Social Forces, 18(4), 560-568.

27. Meyer, C. K., Noe, L. J., Lance J. Noe, Jeffrey A., Geerts, J. A., \& Frank, G. L. (2010). Human Relations in Action. Des Moines, IA: Millennium HRM Press.

28. Meyer, C. K., Noe, L. J., Lance J. Noe, Jeffrey A., Geerts, J. A., \& Frank, G. L. (2010). Organizational change: Technology, workplace, workforce. Des Moines, IA: Millennium HRM Press.

29. Meyer, C. K., Noe, L. J., Lance J. Noe, Jeffrey A., Geerts, J. A., \& Frank, G. L. (2012). Managing people as assets. Des Moines, IA: Millennium HRM Press.

30. Mierlo, E. V. SAP Customer Success Story. Interpolis. Retrieved March 3, 2010 from www.interpolis.nl

31. Miller, N. G., Pogue, D., Gough, Q. D., \& Davis, S. M. (2009). Green buildings and productivity. Journal of Sustainable Real Estate, 1(1), 65-89.

32. Rainey, H. G. (2009). Understanding and managing public organizations (4th ed.). San Francisco: JosseyBass.

33. Reina, D. S., \& Reina, M. L. (1999). Trust and betrayal in the workplace. San Francisco: Berret-Koehler.

34. Schijndel, P. V. Those who trust others are trusted in return. Smart Building Smart Working. Veldhoen \& Company. Retrieved February 28, 2010 from http://www.veldhoen.nl/

35. Schoorman, F. D., Mayer, R. C., \& Davis J. H. (2007). An integrative model of organizational trust: Past, present, and future. Academy of Management Review, 32(2), 344-354.

36. Seglin, J. L. (1998). The Enlightened Manager's Guidebook. Inc., 20(14), 44-47.

37. Singh, A., Syal, M., Grady, S. C., \& Korkmaz, S. (2010). Effects of green buildings on employee health and productivity. American Journal of Public Health, 100(9), 1665-1668.

38. Soloman, R. C. (1993). Ethics and excellence: Cooperation and integrity in business. New York: Oxford University Press.

39. Stanley, D. J., Meyer, J. P., \& Topolnytsky, L. (2005). Employee cynicism and resistance to organizational change. Journal of Business and Psychology, 19(4), 429-459.

40. Williams, M. (2001). In whom we trust: Group membership as an affective context for trust development. Academy of Management Review, 26(3), 377-396.

41. Williamson, O. E. (1985). The economic institutions of capitalism. New York: The Free Press. 


\section{Case: Eupsychian Management: Organizational Change, Behavior, Motivation, and Trust}

Name:

Case Log and Administrative Journal Entry

This case analysis and learning assessment may be submitted for either instructor or peer assessment.

\section{Case Analysis:}

Major case concepts and theories identified:

- What is the relevance of the concepts, theories, ideas, and techniques presented in the case to that of public or private management?

- $\quad$ Facts - what do we know for sure about the case? Please list.

- Who is involved in the case (people, departments, agencies, units, etc.)? Were the problems of an "intra/interagency" nature? Be specific.

- $\quad$ Are there any rules, laws, regulations or standard operating procedures identified in the case study that might limit decision-making? If so, what are they?

- Are there any clues presented in the case as to the major actor's interests, needs, motivations, and personalities? If so, please list them.

\section{Learning Assessment:}

- What do the administrative theories presented in this case mean to you as an administrator or manager?

- How can this learning be put to use outside the classroom? Are there any problems you envision during the implementation phase?

- $\quad$ Several possible courses of action were identified during the class discussion. Which action was considered to be most practical by the group? Which was deemed most feasible? Based on your personal experience, did the group reach a conclusion that was desirable, feasible, and practical? Please explain why or why not.

- $\quad$ Did the group reach a decision that would solve the problem on a short-term or long-term basis? Please explain.

- What could you have done to receive more learning value from this case? 


\section{NOTES}

